\title{
TUHAN DAN KETUHANAN DALAM AJARAN BUDDHA MENURUT PEMAHAMAN MAHASISWA STABN SRIWIJAYA SEMESTER GENAP 2018/2019
}

\author{
Anwar Aman \\ Sekolah Tinggi Agama Buddha Negeri Sriwijaya Tangerang Banten \\ anwaraman@stabn-sriwijaya.ac.id
}

ABSTRAK

Permasalahan penelitian ini adalah berkenaan dengan pemahaman tentang Tuhan dan Ketuhanan mahasiswa semester genap tahun akademik 2018 /2019 Sekolah Tinggi Agama Buddha Sriwijaya. Tujuan penelitian untuk mendeskripsikan pemahaman mahasiswa STABN Sriwijaya terhadap arti dan makna Tuhan dan Ketuhanan agama Buddha. Penelitian juga bertujuan untuk mendeskripsikan pengetahuan mahasiswa terhadap arti dan makna Tuhan dan Ketuhanan dalam agama Buddha sesuai dengan aliran/mazab keagamaan Buddha masing masing dan informasi lainnya yang terkait, bukan untuk mengukur sejauh mana pemahamannya mahasiswa.

Jenis penelitian ini adalah penelitian deskriptif, dengan pendekatan kuantitatif. Subjek penelitian adalah mahasiswa STABN Sriwijaya Tangerang Banten yang berjumlah 78 orang. Objek penelitian adalah pemahaman mahasiswa STABN Sriwijaya terhadap arti dan makna Tuhan dan Ketuhanan agama Buddha. Penelitian ini merupakan penelitian populasi. Pengumpulan datadengan teknik non tes menggunakan kuesioner/angket. Lokasi penelitian yaitu Sekolah Tinggi Agama Buddha Negeri Sriwijaya Tangerang Banten, menggunakan empat klasifikasi berdasarkan skala Likert. Teknik analisis data dengan teknik statistik deskriptif menggunakan nilai rata-rata (mean) dan standar deviasi.

Hasil penelitian menunjukkan bahwa pemahaman mahasiswa STABN Sriwijaya terhadap arti dan makna Tuhan dan Ketuhanan dalam agama Buddha sebesar 64,13\%. Interpretasi yang didapat dengan mencari interval skor persen berdasarkan skala likert menyatakan 64,13\% termasuk dalam kategori tinggi(adaftasi dari rumus Healey). Pemahaman mahasiswa perdimensi kelompok pengetahuan umum dan aliran/mazab, masing masing, yakni pemahaman mahasiswa terhadap terhadap arti dan makna Tuhan dan Ketuhanan berdasarkan dimensi 02 sebesar 56,79\% dalam kategori tinggi, Interpretasi berdasarkan skala likert menyatakan 56,79\%termasuk dalam kategori tinggi. Pemahaman mahasiswa terhadap terhadap arti dan makna Tuhan dan Ketuhanan berdasarkan dimensi 03 sebesar 70,43\% dalam kategori tinggi, Interpretasi berdasarkan skala likert menyatakan 70,43\%termasuk dalam kategori tinggi. Pemahaman mahasiswa terhadap terhadap arti dan makna Tuhan dan Ketuhanan berdasarkan dimensi 04 sebesar 69,20\% dalam kategori tinggi, Interpretasi berdasarkan skala likert menyatakan 69,20\%termasuk dalam kategori tinggi. Pemahaman mahasiswa terhadap terhadap arti dan makna Tuhan dan Ketuhanan berdasarkan dimensi05 sebesar 58,08\% dalam kate gori tinggi, Interpretasi berdasarkan skala likert menyatakan 58,08\%termasuk dalam kategori tinggi.Pemahaman mahasiswa terhadap terhadap arti dan makna Tuhan dan Ketuhanan berdasarkan dimensi 06 sebesar 65,08\% dalam kategori tinggi, Interpretasi berdasarkan skala likert menyatakan 65,08\% termasuk dalam kategori tinggi.

Kata Kunci: Pemahaman Mahasiswa, Arti dan Makna Tuhan dan Ketuhanan 


\section{Pendahuluan}

Berbicara tentang Tuhan, sesungguhnya merupakan sesuatu yang tak mungkin. Agama apapun yang ada di dunia ini tak ada yang mampu berbicara tentang Tuhan. Dalam bahasa manusia, dapat saja orang bertanya siapakah Tuhan itu?

Pertanyaan yang demikian ini sesungguhnya tidak layak, sebab Tuhan bukan makluk apalagi manusia. Pertanyaan siapakah menunjukkan kepada manusia.

Lalu apa yang dibicarakan orang tentang Tuhan? Tidak lain hanyalah gambaran sebatas kemampuan manusia tentang Tuhan, bukan Tuhan dalam pengertian sebenarnya. Apapun yang dibicarakan orang tentang Tuhan itu adalah hanya cerita tentang Tuhan. Lalu Tuhan dalam pengertian sebenarnya itu bagaimana? Jawabnya Tak Dapat Terpikirkan, karena Tuhan berada di luar jangkauan pikiran manusia, sedangkan yang ada dalam pikiran manusia itu hanyalah cerita tentang Tuhan, bukan Tuhan sebenarnya. Karena ketidak mampuan itulah dikatakan Tuhan itu melebihi dari apapun. Adapun yang mengatakan Tuhan itu sesuai dengan kepercayaan masingmasing, seperti Tuhan itu adalah Dzat atau Roh Yang Maha Kudus. Apakah yang dimaksud dengan Dzat itu sama dengan zat yang ada di alam semesta ini atau Roh Yang Maha Kudus itu apakah sama dengan kudusnya manusia. Jawabnya tentu tidak.

Agama Buddha menolak adanya sosok mahakuasa sebagai pencipta dan menyatakan bahwa alam semesta diatur oleh lima hukum kosmis (Niyama Dhamma), yakni Utu Niyama, Bija Niyama, Kamma Niyama, Citta Niyama, dan Dhamma Niyama. Hal ini dipandang oleh banyak orang sebagai perbedaan utama antara Buddhisme dan agama-agama lain. Menurut beberapa tokoh Buddhis (antara lain Almarhum C.Wowor), inilah alasan mengapa Buddha tidak berbicara tentang Tuhan. Lalu apakah tidak berbicara tentang Tuhan sama artinya tidak mengakui adanya Tuhan karena Tuhan pencipta itu tidak ada?. Buddha jelas tidak mengakui adanya Tuhan pencipta, karena Tuhan bukan pencipta. (Brahmajala Sutta). Alam semesta bukan diciptakan melainkan tercipta karena Niyama Dhamma.

Dikatakan dalam Lankavatara Sutra XXVIII, hal. 63, bahwa karena mengingat Tuhan Yang Maha Esa sebagai sesuatu yang tidak mungkin terjangkau dalam alam pikiran manusia, maka Sakyamuni Buddha dengan berbagai cara dan dengan memakai berbagai perumpamaan mencoba menjelaskan perihal Tuhan Yang Maha Esa, antara lain dengan menyebutkan sebagai Hukum yang tunggal (Saddharma Pundarika Sutra). Tathagatagarba merupakan sumbernya semua Tathagata/Para Buddha Penerangan Unggul, disabdakan oleh Sakyamuni Buddha sebagai terang benderang dan Esa.

Pemahaman tentang Tuhan dalam agama Buddha memiliki konsep yang nampaknya walaupun saling melengkapi namun dapat membuat umat Buddha berbeda pemahaman. Masingmasing aliran keagamaan Buddha memiliki konsep sendiri sendiri dengan dalilnya masing-masing yang berdasar kitab suci Buddha dari berbagai aliran keagamaan Buddha pula. Namun semua aliran keagamaan Buddha sepakat, pada Kongres pertama dari Dewan Sangha Buddhis Dunia (WBSC: World Buddhist Sangha Council), Colombo, Sri Lanka, pada 27 Januari 1967 secara aklamasi telah menyepakati 9 poin. Yang nomor tiga adalah tidak meyakini bahwa dunia ini diciptakan dan diatur oleh Tuhan.

Pernyataan ini selain membuat agama Buddha menjadi agama yang "berbeda" dibanding agama-agama pada umumnya. Juga membuat umat Buddha di Indonesia perlu pemahaman lebih lanjut, karena dengan pernyataan tidak menyakini, boleh jadi diartikan tidak percaya atau tidak mengakui Tuhan itu ada. Padahal hidup di Indonesia, yang berideologi Pancasila, setiap warga negara Indonesia harus beragama, berketuhanan Yang Maha Esa. 
Secara umum dalam dunia pendidikan di Indonesia mulai dari pra sekolah sampai perguruan tinggi, dalam mata pelajaran atau mata kuliah agama Buddha diajarkan tentang Tuhan dan Ketuhanan menurut agama Buddha. Pada mulanya semua mata pelajaran dan mata kuliah agama Buddha pada sekolah dan perguruan tinggi umum mengenai Tuhan dan Ketuhanan tidak berbeda, bersumber dari satu sumber yakni Tipitaka, terutama Udana dan Brahmajala Sutta. Perkembangan selanjutan dengan adanya perguruan tinggi agama/keagamaan Buddha, yang memberikan mata kuliah Ketuhanan yang Maha Esa, dijelaskan Tuhan dan Ketuhanan menurut berbagai aliran keagamaan Buddha, karena masing masing aliran/majelis keagamaan Buddha mendirikan perguruan tinggi masing masing sesuai dengan aliran/majelisnya, yang memuat kurikulum dan materi perkuliahan bermuatan lokal, selain nasional. Demikian juga dengan perguruan tinggi agama/keagamaan Buddha negeri, tentu memperkenalkan materi perkuliahan dari semua aliran agama Buddha, termasuk mengenai pemahaman tentang Tuhan dan Ketuhanan.

Dari mahasiswa perguruan tinggi agama/keagamaan Buddha inilah lahir guru guru agama yang sudah dibekali dengan berbagai konsep Tuhan dan Ketuhanan menurut agama Buddha dari semua aliran agama Buddha. Tidak dipungkiri terkadang dari beberapa guru agama Buddha, lebih menekankan bahwa Tuhan atau Ketuhanan dalam agama Buddha adalah sesuai aliran yang dianutnya.

Tentu (menurut asumsi Peneliti) mahas is wa yang baru kuliah yang sudah terbekali konsep mendahuluinya tentang Tuhan atau Ketuhanan berdasarkan apa yang diajarkan gurunya masing masing, ada kemungkinan ketika ditanya tentang Tuhan, jawabnya beraneka ragam. Berbeda dengan mahasiswa yang kuliah pada perguruan tinggi agama Buddha yang melingkupi semua aliran agama/keagamaan Buddha atau dari suatu aliran namun memberikan materi pekuliahan dari semua aliran kegamaan Buddha, memberikan jawaban yang cukup lengkap mengenai Tuhan dan ketuhanan agama Buddha.

Perkiraan ini menarik bagi peneliti, untuk menelusuri lebih lanjut bagaimana pemahaman mahasiswa di Sekolah Tinggi Agama Buddha Negeri Sriwijaya.

\section{Metode Penelitian}

Penelitian ini adalah penelitian deskriptif kuantitatif yaitu mengenai pemahaman mahasiswa STABN Sriwijaya mengenai konsep tuhan dan ketuhanan yang maha esa menurut agama Buddha, artinya dalam penelitian ini peneliti hanya ingin menggambarkan bagaimana pemahaman mahasiswa STAB Sriwijaya mengenai konsep ketuhanan yang maha esa, bukan untuk pengukur kedalaman pemahaman mahasiswa terhadap konsep tuhan dan ketuhanan yang maha esa dan karena itu pada saat penelitian berlangsung tanpa pengujian hipotesis. Penelitian ini merupakan penelitian yang dilakukan terhadap variabel mandiri yaitu tanpa membuat perbandingan atau menghubungkan dengan variabel lain. Metode yang digunakan dalam penelitian ini adalah survey.

Adapun sampel yang digunakan dalam penelitian ini adalah seluruh mah asiswa STABN Sriwijaya tahum akademik 2018/2019 yang merupakan populasi dengan jumlah mahasiswa/i sekitar 100 orang. Populasi tersebut dapat dilihat pada tabel yang akan dibuat kemudian sebagai hasil pengumpulan/pencarian data penelitian ini, karena saat pengambilan data ternyata kurang dari seratus orang maka semua mahasiswa dijadikan sampel penelitian ini. Sampel penelitian dimaksud diambil dari populasi seluruh mahasiswa yang masih aktif dan terdata oleh peneliti, yakni mahasiswa semester dua, empat, dan enam tahun akademik 2018 /2019. Namun ada beberapa orang yang tidak hadir karena mengikuti KKN dan PPL, yang mengisi angket hanya 84 responden. 
Keabsahan data pada penelitian ini menekankan pada aspek validitas dan realibilitas instrumen pengumpulan data yang digunakan. Validitas angket pemahaman tentang Tuhan dan Ketuhanan diuji dengan validitas isi (content validity) melalui expert judgement dan validitas konstruk menggunakan analisis Product Momen Pearson untuk mengetahui seberapa jauh butir butir dalam angket pemahamanan tentang Tuhan dan Ketuhanan mampu mengetahui apa yang benar benar diketahui mahasiswa sesuai dengan definisi konseptual yang diajarkan masing masing mazab/aliran agama Buddha maupun definisi dan referensi secara umum. Relibilitas angket pemahaman tentang Tuhan dan Ketuhanan akan menjamin hasil apa yang telah diketahui dapat dipercaya.

Realibilitas instrumen pada penelitian ini menggunakan rumus Koefisien Alphat Cronbach. Reliabilitas item diuji dengan melihat koefisien alpha dengan melakukan reliability analysis dengan SPSS ver. 15.0 for Windows. Akan dilihat nilai Alpha Cronbach untuk reliabilitas keseluruhan item dalam satu variabel. Jika nilai alpha>0,7 artinya reliabilitas terpenuhi (sufficient reliability) sementara jika alpha $>0,80$ ini mensugestikan seluruh item reliabel dan seluruh tes konsisten secara internal karena memiliki reliabilitas yang kuat. Ada pula yang memaknai sebagai berikut: Jika alpha>0,90, maka reliabilitas sempurna, Jika alpha antara 0,70 - 0,90 maka reliabilitas tinggi, Jika alpha antara 0,50 - 0,70 maka reliabilitas moderat, Jika alpha <0,50 maka reliabilitas rendah (Perry Roy Hilton \& Charlotte Brownlow, 2004: 364). Reabilitas angket pemahaman Tuhan dan Ketuhanan dalam agama Buddha mahasiswa STABN Sriwijaya, sebesar 0,925 dinyatakan sempurna atau tertinggi karena lebih dari 0,90.

Reliability Statistics

\begin{tabular}{|r|r|}
\hline $\begin{array}{c}\text { Cronbach's } \\
\text { Alpha }\end{array}$ & N of Items \\
\hline 0,925 & 78 \\
\hline
\end{tabular}

Teknik analisis data menggunakan teknik statistik deskriptif menggunakan nilai rata-rata (mean) dan standar deviasi untuk menentukan kategori tingkat pemahaman mahasiswa menjadi kategori tinggi, sedang, dan rendah (Sudijono, 2011). Sedangkan persentase tingkat pemahaman mahas iswa didapatkan melalui membagi skor total jawaban responden dengan skor total maksimal jawaban responden, kemudian dikalikan dengan 100. Skor total jawaban responden mewakili nilai kenyataan yang diterima mahasiswa berkaitan dengan pemahaman mahasiswa tentang Tuhan dan Ketuhanan dalam agama Buddha. Sedangkan skor total maksimal merupakan nilai maksimal pemahaman mahasiswa terhadap Tuhan dan Ketuhanan dalam agama Buddha.

\section{Pembahasan}

Perkembangan keagamaan Buddha tidak luput dari adaftasi sinkritis membawa keadaan disrupsi pada berbagai bidang kehidupan masyarakat. Disrupsi pada bidang teknologi berkembang pesat kearah perubahan akibat digitalisasi dan internet of thing. Dari sisi keagamaan merupakan keadaan atau perubahan yang melahirkan pengetahuan keagamaan yang tercerabut dari akarnya. Tidak sedikit berbagai pemahaman keagamaan khususnya bagi umat Buddha termasuk mahasiswa Buddhis, karena ketidak mengertian terhadap Buddha sasana (ajaran Buddha) menjadikan tidak sedikit umat yang mengaku beragama Buddha memiliki pengetahuan yang tidak lagi relevan dengan ajaran Buddha dan itu terjadi pada masa masa lalu bahkan juga sekarang, akhirnya kemampuan beradaptasi terhadap perkembangan masyarakat menjadi kunci keberhasilan yang 
harus segera terimplementasikan, tidak terkecuali kemungkinan terjadi pada mahasiswa, adaptasi terhadap perkembangan keagamaan dirasa atau terpikirkan dimungkinkan untuk menjawab berbagai kebutuhan masyarakat modern menjadi kunci keberhasilan dalam menjalankan kehidupan di dunia. Sayangnya harapan itu membuat terciptanya sebuah pemahaman palsu bahkan keliru terhadap ajaran Buddha yang mungkin didapat dari informasi berupa tafsiran adaftasi, yang berimbas pada mahasiswa yang juga menjadi komponen penting dalam kualitas dan proses pelayanan pendidikan pada sebuah perguruan tinggi. Apakah hal ini juga terjadi pada mahasiswa STABN Sriwijaya? Pertanyaan inilah yang merupakan sumber inspirasi peneliti untuk melakukan penelitian ini.

Berdasarkan validitas terhadap butir butir instrument dilakukan melalui expert judgement dan validitas konstruk menggunakan analis is Product Momen Pearson, terdapat tujuh butir yang tidak valid ( $38,47,50,52,78,83,85)$ dari berasal empat dimensi $(3,4,5$ dan 6$)$, dengan instrument keseluruhan berjumlah delapan puluh lima butir instrument, berarti dapat dikatakan 91,76\% adalah Valid.

Berdasarkan reabilitas angket pemahaman Tuhan dan Ketuhanan dalam agama Buddha mahasiswa STABN Sriwijaya, sebesar 0,925, instrument penelitian dinyatakan sempurna atau tertinggi karena lebih dari 0,90 (rumus Koefisien Alphat Cronbach).

Berdasarkan jawaban responden dari masing masing dimensi, dapat diketahui sebagai berikut:

\begin{tabular}{|c|c|c|c|}
\hline \multicolumn{2}{|l|}{ INTERPRETASI } & Arikunto & S. Linkert \\
\hline Pemahaman Dimensi 01 & 61,33 & CUKUP & TINGGI \\
\hline Pemahaman Dimensi 02 & 56,79 & KURANG & TINGGI \\
\hline Pemahaman Dimensi 03 & 70,43 & CUKUP & TINGGI \\
\hline Pemahaman Dimensi 04 & 69,20 & CUKUP & TINGGI \\
\hline Pemahaman Dimensi 05 & 58,08 & RENDAH & TINGGI \\
\hline Pemahaman Dimensi 06 & 65,08 & CUKUP & TINGGI \\
\hline
\end{tabular}

Berdasarkan jawaban respoden perdimensi, yang secara keseluruhan dapat dilihat pada dimensi 06, pemahaman mahasiswa STABN Sriwijaya terhadap arti dan makna Tuhan dan Ketuhanan agama Buddha, sebesar 65,08, kategori cukup (Arikunto) dan berdasarkan skala linket dikategorikan tinggi.

Berdasarkan perhitungan nilai persentase pemahaman mahasiswa STABN Sriwijaya terhadap arti dan makna Tuhan dan Ketuhanan agama Buddha adalah sebesar 64,13\%, termasuk dalam kategori tinggi bila berdasarkan rumus Skala Likert dan dalam kategori cukup bila berdasarkan rumus interpretasi Arikunto. Nilai tersebut didapatkan atas jawaban responden terhadap angket yang disampaikan peneliti. Dari hasil analisis data ini dapat dipahami mahasiswa STABN Sriwijaya, meskipun memiliki kemampuan beradaftasi yang tinggi, namun memiliki pengetahuan yang cukup atau tinggi terhadap ajaran Buddha, khususnya mengenai arti dan makna Tuhan dan Ketuhanan, hal ini juga tergambar pada dimensi pemahaman secara keseluruhan dengan nilai pemahaman 65,08. Lepas perkiraan (hipotesa) yang berdasarkan penelitian terdahulu dinyatakan tidak sedikit umat Buddha (termasuk mahasiswa) yang kebingungan terhadap pemahaman Tuhan dan Ketuhanan dalam agama Buddha, bahkan tidak tahu sehingga menganggap sama dengan tuhan dan ketuhanan agama lain.

Berdasarkan kenyataan atau hasil penelitian yang peneliti lakukan terhadap mahasiswa Sekolah Tinggi Agama Buddha Negeri Sriwijaya Tangerangnutup Banten, ternyata berbeda 
arti dan makna Tuhan dan Ketuhanan agama Buddha dari berbagai aliran/mazab keagamaan Buddha bahkan mampu membedakannya dari pengertian Tuhan dan Ketuhanan secara umum.

\section{Penutup}

Dari hasil analisis data dan pembahasan, dapat diambil kesimpulan sebagai berikut:

a. Pemahaman mahas is wa terhadap arti dan makna Tuhan dan Ketuhanan secara totalitas sebesar $64,13 \%$. Interpretasi yang didapat dengan mencari interval skor persen berdasarkan skala likert menyatakan 64,13\% termasuk dalam kategori tinggi (adaftasi dari rumus Healey).

b. Pemahaman mahasis wa terhadap terhadap arti dan makna Tuhan dan Ketuhanan berdasarkan dimensi 01 sebesar $61,33 \%$ dalam kategori tinggi, Interpretasi berdasarkan skala likert menyatakan $61,33 \%$ termasuk dalam kate gori tinggi.

c. Pemahaman mahasiswa terhadap terhadap arti dan makna Tuhan dan Ketuhanan berdasarkan dimensi 02 sebesar 56,79\% dalam kategori tinggi, Interpretasi berdasarkan skala likert menyatakan $56,79 \%$ termasuk dalam kategori tinggi

d. Pemahaman mahasis wa terhadap terhadap arti dan makna Tuhan dan Ketuhanan berdasarkan dimensi 03 sebesar 70,43\% dalam kategori tinggi, Interpretasi berdasarkan skala likert menyatakan $70,43 \%$ termasuk dalam kategori tinggi

e. Pemahaman mahasiswa terhadap terhadap arti dan makna Tuhan dan Ketuhanan berdasarkan dimensi 04 sebesar 69,20\% dalam kategori tinggi, Interpretasi berdasarkan skala likert menyatakan $69,20 \%$ termasuk dalam kate gori tinggi

f. Pemahaman mahasiswa terhadap terhadap arti dan makna Tuhan dan Ketuhanan berdasarkan dimensi 05 sebesar 58,08\% dalam kategori tinggi, Interpretasi berdasarkan skala likert menyatakan $58,08 \%$ termasuk dalam kategori tinggi.

g. Pemahaman mahasis wa terhadap terhadap arti dan makna Tuhan dan Ketuhanan berdasarkan dimensi 06 sebesar 65,08\% dalam kategori tinggi, Interpretasi berdasarkan skala likert menyatakan $65,08 \%$ termasuk dalam kategori tinggi.

\section{Daftar Pustaka}

Kamus Besar Bahasa Indonesia

Kitab Suci Tipitaka dan Tripitaka

Arikunto, S. 2016. Prosedur Penelitian Suatu Pendekatan Praktik. Jakarta: Renika Cipta.

Kandahjaya, Hudaya. 1989. Adi Buddha dalam Agama Buddha Indonesia. Forum Pengkajian Agama Buddha di Indonesia.

Linkert, Rensis. 1932. A Technique for the Measurement of Attitudes. New York: The Science Press.

Nasruddin Umar. 2019. Konsep Ketuhanam dalam agama Buddha. Jakarta: Fakultas Ushuluddin UIN Syarif Hidayatullah.

Madiyono, 2018. Signifikasi Konsep Ketuhanan Yang Maha Esa Bagi Umat Buddha di Tangerang. Tangerang: STABN Sriwijaya

Samuel Shaw. 1989. Communion with God, quoted in Albert C. Outler, 'Pietism and Enlightenment: Alternatives to Tradition' in Louis Dupre and Don E. Saliers (eds.), New York and London: Christian Spirituality: Post Reformation and Modern.

Sapardi. ----. Pendidikan Agama Buddha. Jakarta: Universitas Indonesia.

Sugiyono.2012.Metode Penelitian Kuantitatif Kualitatif Dan R\&D. Bandung:

Alfabet $a$.

Wawan Daryoko. ...... Buddhisme dan Gusti: Dialektika Buddhisme dan Kearifan Lokal.

Tangerang: STABN Sriwijaya. 